\title{
Monika Kucner
}

Katedra Literatury i Kultury Niemiec, Austrii i Szwajcarii

Wydział Filologiczny

Uniwersytet Łódzki

\section{Twórczość literacka społeczności niemieckojęzycznej w Lodzi w XIX i na początku XX wieku}

\section{Uwagi wstępne}

Wśród coraz bogatszej literatury na temat wielokulturowej przeszłości Łodzi brak jest badań, które w sposób syntetyczny przedstawiałyby twórczość literacką niemieckojęzycznych łodzian ${ }^{1}$. Pierwsze opracowania na ten temat pojawiły się pod koniec lat trzydziestych XX w. Wśród nich na uwagę zasługuje publikacja germanisty, historyka oraz badacza tzw. niemczyzny zagranicznej, Karla Kurta Kleina, z roku 1939 pt. Literaturgeschichte des Deutschtums im Ausland. Schriftum und Geistesleben der deutschen Volksgruppen im Ausland vom Mittelalter bis zur Gegenwart ${ }^{2}$, w której autor zredukował środowisko literackie Łodzi do pisarzy związanych głównie z nurtem tzw. Heimatliteratur 3 . Powyższe opracowanie wywarło tak duże piętno na obrazie literatury niemieckojęzycznej,

${ }^{1}$ Za podstawowe pojęcie w niniejszej pracy należy uznać termin „literatura niemieckojęzycznych łodzian”. Problem ,języka” odzwierciedla złożoność semantyczną zaproponowanej formuły. Autorka chce zwrócić uwagę, że twórcami były nie tylko osoby pochodzenia niemieckiego, ale również żydowskiego, które tworzyły w języku niemieckim.

${ }^{2}$. K. Klein, Literaturgeschichte des Deutschtums im Ausland. Schrifttum und Geistesleben der deutschen Volksgruppen im Ausland vom Mittelalter bis zur Gegenwart, Leipzig 1939, 2, Auflage 1977.

${ }^{3}$ Heimatliteratur - literatura ojczyźniana/małoojczyźniana. Rozwój tej literatury związany jest z powstaniem na przełomie XIX i XX w. niemieckiego ruchu sztuki ojczyźnianej oraz utworzeniem Związku Rolników. Nadrzędnym celem było budzenie świadomości narodowej oraz polityczna i społeczna konsolidacja państwa niemieckiego. Wartości, jakie niosła ze sobą to negacja współczesnej cywilizacji i przeciwstawianie ich naturze oraz społeczności wiejskiej, krytyka kapitalizmu. Poezja stała się ważnym czynnikiem poznania. Na początku XX w. literatura ojczyźniana zaczęła propagować najbardziej konserwatywne idee Drugiej Rzeszy. Naród stał się wielkością zmistyfikowaną, której nie można ująć w kategoriach społecznych. Por. J. Zaprucki, Kultura Reminiscencji. Reminiscencje kultury, Motyw matej ojczyzny w twórczości Siegfrieda Lenza, Horsta Bienka i Johannesa Bobrowskiego, Jelenia Góra 2006; Cz. Karolak, W. Kunicki, H. Orłowski, Dzieje kultury niemieckiej, Warszawa 2007. 
że większość prac, które powstały po tym okresie, powielało ten niepełny obraz natomiast podjęciu nowych badań nie sprzyjała sytuacja polityczna w Polsce po II wojnie światowej. Przełom nastąpił dopiero w ostatnich latach, kiedy do badań włączono prasę jako materiał źródłowy. Wtedy okazało się, że lokalne gazety o różnym rodowodzie społeczno-politycznym w miarę regularnie prezentowały dorobek literacki niemieckojęzycznych autorów, który może stać się podstawą solidnej analizy i interpretacji. Szeroko pojęte badania nad literaturą niemieckojęzycznych łodzian przybierają na intensywności ${ }^{5}$. Niniejszy artykuł prezentuje jedynie fragment badań na ten temat, które wymagają dalszych wnikliwych analiz i uzupełnień.

\section{2. Życie literackie}

W XIX i na początku XX w. Łódź była przestrzenią społeczną, w której istniało wiele paradygmatów kulturowych. Dzięki różnorodności to małe, niewiele znaczące miasteczko zmieniło się $\mathrm{w}$ prężnie działający ośrodek przemysłowy, który przyciągał tysiące przybyszów z kraju i z zagranicy. Rozwój miasta, a wraz $\mathrm{z}$ nim zmiany $\mathrm{w}$ strukturze narodowościowej oraz wyznaniowej powodowały, że życie literackie kształtowało się w sposób specyficzny, z dala od wielkich ośrodków kultury, takich jak Kraków, Wilno czy Warszawa. Miasto nie zdołało wykształcić na przestrzeni wielu lat, tj. od jego powstania aż do momentu pojawienia się pierwszych niemieckojęzycznych osadników w latach dwudziestych XIX w., „wzorców kulturowych, do których mogłaby nawiązywać przybywająca

\footnotetext{
${ }^{4}$ Por. m. in. O. Heike, Das Deutschtum in Polen 1918-1939, Bonn 1955; O. Heike, Die deutsche Minderheit in Polen bis 1939. Ihr Leben und Wirken kulturell, gesellschaftlich, politisch, Leverkusen 1985 czy R. Gerlach-Damaschke, Dichtung im Kontext der Geschichte. Zur Literatur der Deutschen in und aus Polen, [w:] Beiträge zur deutsch-polnischen Nachbarschaft, hrsg. von C. J. Kenez, Helmut Neubach und J. Rogall, Berlin-Bonn 1992, tu s. 34-40; A. Breyer, Neuerscheinungen im Deutschen Schrifttum Mittelpolens (1925-1930), „Deutsche Blätter in Polen”, Nr. 8, 1931, s. 227-230.

${ }^{5}$ Por. K. A. Kuczyński, E. Mehnert, B. Ratecka (red.), Lodz in derdeutschsprachigen Literatur. Eine Anthologie, Łódź 2005; B. Ratecka, Niemiecki pegaz w Lodzi, Szkic o twórczości literackiej Niemców łódzkich, [w:] Niemcy w dziejach Łodzi do 1945 r., red. K. A. Kuczyński i B. Ratecka, Łódź 2001, s. 235-257; B. Ratecka, Obraz Łodzi w literaturze Niemców lódzkich, [w:] Wizerunek Łodzi w literaturze, kulturze i historii Niemiec i Austrii, materiały z konferencji, Łódź 2005, s. 81-108; M. Kucner, Lodz in den feuilletonistischen Texten von Carl Heinrich Schultz (1882-1940), [w:] Lodz jenseits von ,Fabriken, Wildwest und Provinz “, Hrsg. S. Dyroff, K. Radziszewska, I. Röskau-Rydel, München 2009; M. Kucner, Deutschsprachige Literatur in Lodz bis 1939, [w:] Studia i szkice dedykowane Julianowi Baranowskiemu, red. E. Wiatr, P. Zawiski, Łódź 2010; M. Kucner (red.) przy współpracy z W. Kesslerem, Literackie i nieliterackie obrazy miasta. Lódź przełomu wieków oczami niemieckojęzycznego autora - Carla Heinricha Schultza/Nicht nur literarische Bilder einer Stadt. Lodz in den Augen eines deutschsprachigen Autors - Carl Heinrich Schultz, Łódź 2011.
} 
ludność 6 . Łódź była więc u progu rozwoju przemysłowego ośrodkiem bez historii oraz kultury, z którymi można by się było utożsamiać.

Życie literackie miasta rodziło się w trudnych warunkach. Wprawdzie tempo przyrostu ludności w drugiej połowie XIX w. w Łodzi było imponujące, to jednak dość wolno rozwijały się wszelkie instytucje, sprzyjające rozpowszechnianiu produktów pracy literackiej, takie jak biblioteki, wydawnictwa oraz księgarnie? Pierwsza biblioteka powstała w latach dwudziestych XIX w. przy łódzkiej szkole elementarnej. Jej księgozbiór zawierał kilka książek polskich z zakresu metodyki nauczania. W późniejszym okresie znacznie się rozrósł i obejmował już nie tylko publikacje w języku polskim, ale również rosyjskim i niemieckim. Kolejne biblioteki, które stopniowo tworzono w Łodzi również zawierały wielojęzyczne księgozbiory. I tak np. biblioteki przy szkołach Łódzkiego Towarzystwa „TalmudTora" posiadały publikacje w języku hebrajskim i rosyjskim ${ }^{8}$. Oprócz bibliotek dostęp do książki gwarantowały łódzkie księgarnie m. in. L. Fiszera, C. Richtera, S. Strakuna, R. Horna oraz A. Straucha, przy których znajdowały się wypożyczalnie. Podobnie jak biblioteki obejmowały księgozbiór, który odzwierciedlał wielonarodowy charakter miasta. Przeważała głównie beletrystyka, publikacje o charakterze popularnonaukowym oraz naukowym. Choć tych ostatnich było najmniej.

Niemieckojęzyczna ludność Łodzi miała więc dostęp do książki. Stowarzyszenia takie, jak niemiecki Gewerkschaft Evangelischer Textilarbeiter, posiadały dodatkowo duże biblioteki, dysponujące przede wszystkim księgozbiorem niemieckojęzycznym. Również niemieccy fabrykanci, tacy jak L. Geyer, K. Scheibler, J. Kunitzer czy L. Grohmann posiadali prywatne biblioteki, które stale wzbogacali o nowe tytuły. W ich księgozbiorach znajdowała się często literatura klasyczna: G. E. Lessing, J. G. Herder, A. Puszkin, N. Gogol. Zainteresowanie czytelnictwem wśród niemieckojęzycznych łodzian stale rosło. Powszechne stało się jednak dopiero $\mathrm{w}$ drugim i trzecim pokoleniu, bowiem były to już osoby wykształcone, wykazujące zainteresowania kulturą. Poza tym studia, które odbywali w zagranicznych uczelniach, zobowiązywały do znajomości najnowszych oraz klasycznych utworów literatury światowej.

Mimo iż stopniowo powstawały biblioteki, gromadzono książki, to jednak przez długi czas brak było w Łodzi odpowiedniej publiczności, którą charakteryzują określone wzory i standardy kultury literackiej. Na przełomie wieków

${ }^{6}$ Por. A. Barszczewska-Krupa, Rodowód oraz drogi rozwoju kultury i oświaty w Lodzi. Uwagi ogólne, [w:] Łódź. Dzieje miasta, t. 1, red. R. Rosin, t. 1: do roku 1918, red. B. Baranowski, J. Fijałek, Łódź-Warszawa 1980, wyd. 2, 1988, s. 480-486.

${ }^{7} \mathrm{Na}$ temat instytucji literackich oraz czytelnictwa por. m. in. E. Pleszkun-Olejniczakowa, Instytucje literackie w Łodzi międzywojennej i ich rola kulturotwórcza, Łódź 1996; J. Konieczna, Kultura książki polskiej w Lodzi 1820-1918, Łódź 2005; J. Krajewska, Czytelnictwo wśród robotników w Królestwie Polskim 1870-1914, Warszawa 1979.

${ }^{8}$ Por. A. Barszczewska-Krupa, op. cit. 
najliczniejszą grupę społeczną w Łodzi tworzyli robotnicy zatrudnieni w przemyślè. Znaczna część osób trudniła się poza tym handlem i rzemiosłem. Duży odsetek ludności stanowili służący, wyrobnicy, wozacy i tragarze. Osoby wykonujące wolne zawody, w tym urzędnicy, duchowieństwo, nauczyciele, stanowiły niewielki procent społeczeństwa. Szacuje się, że pod koniec XIX w. tzw. inteligencja stanowiła niespełna 3\% ogółu mieszkańców ${ }^{10}$. Dość niski odsetek ludności, która była w miarę dobrze wykształcona oraz mogła nadawać ton życiu kulturalnemu miasta, dodatkowo komplikował wysoki poziom analfabetyzmu ${ }^{11}$. W powszechnym spisie ludności z 1931 r. zanotowano, iż na „604 tys. mieszkańców czytać i pisać umiało 393 239, nie umiało czytać i pisać 81 357, tylko czytać 14205 osób"'2. Analfabetyzmem była dotknięta przeważnie ludność polska. Ludność niemiecka wypadała na tym tle dość dobrze. Można przyjąć, że odsetek ludności niepotrafiącej ani czytać, ani pisać w tej grupie narodowej był najmniejszy ${ }^{13}$. Wśród Niemców znaczna część była właścicielami fabryk oraz zajmowała stanowiska kierownicze. Sporo było również robotników fabrycznych, natomiast mniej osób pracowało $w$ handlu oraz rolnictwie. $Z$ czasem Niemcy zaczęli tworzyć poważną część burżuazji przemysłowej, która miała istotny wpływ na społeczny, ekonomiczny i kulturalny rozwój miasta ${ }^{14}$. Ich działalność koncentrowała się od początków przybycia do Łodzi wokół zgromadzeń rzemieślniczych oraz towarzystw, w ramach których kultywowano tradycje wyniesione z dawnych stron ojczystych. Już w roku 1824 utworzono Lodzer Bürgerschützengilde (Łódzkie Towarzystwo Strzeleckie), a po nim pojawiły się kolejne, m. in. Lodzer Männergesangverein (Łódzkie Męskie Towarzystwo Śpiewacze), Deutscher Schul- und Bildungsverein (Niemieckie Towarzystwo Szkolno-Oświatowe) czy w końcu Verein deutschsprechender Meister und Arbeiter (Związek Niemieckojęzycznych Tkaczy i Robotników). Oprócz działalności w licznych towarzystwach, niemieckojęzyczni łodzianie rozwinęli też mecenat nad wieloma artystami-plastykami, malarzami, rzeźbiarzami. Wspierano również działalność teatralną. Mimo iż podejmowanych było wiele znaczących inicjatyw na polu kultury, to jednak ludność ta okazała się zbyt słaba, aby stworzyć stowarzyszenia oraz związki o charakterze zawodowym, ekonomicznym i towarzyskim, które skupiłyby grupę zainteresowaną tworzeniem literatury i sztuki, porównywalną z polskim „Skamandrem” czy żydowskim ,Jung Idysz". Nieliczna miejscowa inteligencja, głównie napływowa, z trudem walczyła

${ }^{9}$ Por. badania na temat struktury społecznej mieszkańców Łodzi: J. K. Janczak, Struktura spoleczna ludności Łodzi a latach 1820-1918, [w:] Polacy - Niemcy - Żydzi w Lodzi w XIX-XX w. Sąsiedzi dalecy i bliscy, red. P. Samuś, Ibidem, Kurowice k/Łodzi 1997.

${ }^{10}$ Por. ibidem.

${ }^{11}$ Por. ibidem.

${ }^{12}$ Cyt. za J. Tynecki, Łódzki rynek prasowy w dwudziestoleciu międzywojennym, „Prace Polonistyczne" 1983, ser. XXXIX, 1983, s. 260.

${ }_{13}$ Por. J. K. Janczak, op. cit.

${ }^{14}$ Por. S. Pytlas, Lódzka burżuazja przemysłowa w latach 1864-1914, Łódź 1994. 
z kulturalnym zaniedbaniem miasta. Ludwik Stolarzewicz, autor jednej z pierwszych antologii na temat literatury Łodzi, tak pisał o kulturze miasta:

W mieście, w którem „interes” był wszystkiem, w mieście, w którem wszystko kręciło się wokół pytania, czy bawełna spada, czy ceny idą w górę, gdzie sprzedać, dokąd wysłać towar, nie było wprost czasu na myśli o literaturze - nauce - sztuce! $!^{15}$

Przytoczona refleksja dobrze oddaje ducha czasu. W Łodzi nie było niemieckojęzycznych grup literackich, stawiających sobie wspólne cele, dążących do realizacji wspólnych zamierzeń artystycznych. Brak ten powodował, że ówczesny status społeczny i zawodowy pisarza był niski. Wielu autorów to przedstawiciele takich zawodów, jak lekarz, adwokat, nauczyciel, dziennikarz i publicysta, którzy nie posiadali doświadczeń literackich. Deficyt ten jednak starały się nadrabiać szkoła oraz lokalna prasa. W okresie międzywojennym w niektórych niemieckich szkołach zainicjowano powstanie kółek literackich. Do nich należały $\mathrm{m}$. in. niemieckojęzyczny Schillerkreis oraz Integer vitae, oba działały przy Lodzer Deutsches Gymnasium (Niemieckim Gimnazjum Łódzkim) ${ }^{16}$. Kółka literackie były prowadzone przez nauczycieli, którzy często organizowali je w swoich mieszkaniach ${ }^{17}$. Uczniowie na lekcjach języka niemieckiego zapoznawali się z twórczością literacką wielu wybitnych pisarzy, takich jak: Johann Wolfgang von Goethe, Friedrich Schiller, Richard Voss, Paul Keller, Thomas Mann, Georg Kaiser, Kasimir Edschmid. Czytano m. in. Cierpienia młodego Werthera, Fausta, Ifigenie w Taurydzie, Hermanna und Dorothee, Trylogie o Wallensteinie $i$ wojnie trzydziestoletniej, Marię Stuart, Don Carlosa, Buddenbrocków. Wśród obowiązkowych lektur znalazły się również Polenlieder Augusta von Platena - polityczne pieśni i wiersze skomponowane na przestrzeni lat 1830-1849 na cześć polskich dążeń niepodległościowych przez takich poetów i literatów, jak Franz Grillparzer, Gottfried Keller, Ludwig Uhland i Annette von Droste-Hülshoff ${ }^{18}$. Oprócz twórczości niemieckojęzycznych pisarzy młodzi odbiorcy literatury mieli możliwość zapoznania się z twórcami polskimi, takimi jak Adam Mickiewicz, którego fragmenty Dziadów i Pana Tadeusza omawiano podczas spotkań z literaturą. Odwoływano się również do twórczości rosyjskich autorów: Fiodora Dostojewskiego, Lwa Tołstoja, Nikołaja Gogola i Nikołaja Leskowa. Młodzi ludzie, wzorując się na kanonie europejskiej literatury, tworzyli własne teksty, które

${ }^{15}$ L. Stolarzewicz, Literatura Łodzi w ciagu jej istnienia. Szkic literacki i antologia, Łódź 1935, s. 8.

${ }^{16}$ Por. F. Weigelt, Das Lodzer Deutsche Gymnasium. Gedenkschrift zur Gründung des LDG am 29. November 1906 und zur Feier des 50. Jubiläums in Weinheim, Weinheim 1956.

${ }^{17}$ Por. S. Waade, Die Angel. Eine Liebeserklärung für Lydia Bauer, [w:] F. Weigelt, Penne, Pauker und Pennäler. Eine Gedenkschrift für die Lodzer deutschen Gymnasien 1866-1945, Selbstverl. des Kuratoriums für das LDG, Wuppertal 1972.

${ }^{18}$ Por. F. Weigelt, op. cit. 
prezentowali później na łamach lokalnej prasy oraz w konkursach literackich ${ }^{19}$. Byli oni jednak zbyt młodzi, aby prowadzić ważkie polemiki, które pobudziłyby rozwój intelektualny łódzkich elit.

Oprócz szkoły w kształtowaniu idei artystycznych istotne miejsce zajmowała prasa, która przejęła funkcję salonu i kawiarni literackiej. Wiodącą rolę odgrywały takie niemieckojęzyczne pisma, jak: „Lodzer Zeitung” ${ }^{20}$, „Neue Lodzer Zeitung”,21, „Freie Presse”22, „Der Deutsche Wegweiser"23 oraz ich dodatki beletrystyczne, jak np.: „Illustrierte Sonntagsbeilage”, „Illustriertes Sonntagsblatt”, „Illustriertes Wochenblatt”, „Die Welt im Bilde” jak również „Lodzer Frauen Zeitung". W okresie dwudziestolecia międzywojennego czasopisma te stawiały

${ }^{19}$ W dodatku do „Neue Lodzer Zeitung” pt. „Die Welt im Bilde” redakcja opublikowała obszerny artykuł na temat utworzenia miesięcznika dla młodzieży „Die Biene”, w którym opublikowano $\mathrm{m}$. in. wiersze początkujących łódzkich autorów, m. in. uczniów gimnazjum A. Rothert; [b.a.]Die Biene, „Die Welt im Bilde. Sonntagsbeilage zur Neuen Lodzer Zeitung” 6.10.1927, s. 4-5.

${ }^{20}$ „Lodzer Zeitung” - gazeta łódzka, która ukazywała się w Łodzi od 1865 r. trzy razy w tygodniu, a od 1881 codziennie. Była następczynią pierwszego polsko-niemieckiego pisma o charakterze urzędowym „Łodźer Anzeiger - Łódzkie Ogłoszenia”. Ostatni numer „Lodzer Zeitung” ukazał się w lutym 1915 r. Założycielem i wydawcą był Johann Petersilge, a po jego śmierci w roku 1905 członkowie rodziny. Z gazetą współpracowali m. in.: August Thiele, Leopold Zoner, Aleksander Milker, Alexis Drewing, Karl Wilkens, Maks Warrikow, Karl Schmidt. Obok głównego wydania ukazywały się dodatki beletrystyczne „Belletristische Sonntagsbeilage”, „Illustrierte Sonntagsbeilage” oraz „Humoristische Beilage”.

${ }^{21}$ „Neue Lodzer Zeitung” - gazeta niemieckojęzyczna, zaczęła ukazywać się w 1902 r. pod nazwą „Neue Lodzer Zeitung. Handels- und Industrieblatt”. Wydawcami i redaktorami byli Alexis Drewing i Aleksander Milker. Gazeta prezentowała liberalny profil polityczny. Była zazwyczaj ugodowo nastawiona wobec Polski i Polaków. Cieszyła się dużą popularnością wśród łódzkich czytelników. Wraz z gazetą ukazywały się liczne dodatki beletrystyczne, takie jak: „Illustrierte Sonntagbeilage”, „Illustriertes Sonntagsblatt”, „Illustriertes Wochenblatt”, „Die Welt im Bilde” czy „Lodzer Frauen Zeitung”. Oprócz dodatków publikowano również kalendarze z licznymi artykułami dotyczącymi historii i kultury Łodzi.

22 „Lodzer Freie Presse” - gazeta niemieckojęzyczna, zaczęła ukazywać się w 1918 r. Często zmieniała swoją nazwę. W latach 1918-1923 ukazywała się jako „Lodzer Freie Presse”, 1923-1939 „Freie Presse”, od numeru 159 do 307 (1939) nosiła nazwę „Deutsche Lodzer Zeitung”, od numeru 308 (1939) do numeru 101 (1940) „Lodscher Zeitung mit den amtlichen Bekanntmachungen der deutschen Militär-und Zivilbehörden", od numeru 102 w roku 1940 aż do 1945 r. nazywała się „Litzmannstädter Zeitung mit den amtlichen Bekanntmachungen für Stadt und Kreis Litzmannstadt”. Była pismem o charakterze narodowo-niemieckim. Skupiła wokół siebie czołowych działaczy politycznych: Adolfa Kargela, Eduarda Behrensa, Hugo Wieczorka. Wraz z pismem drukowano dodatki, takie jak: „Die Zeit im Bild” oraz „Textilmarkt”.

23 „Der Deutsche Wegweiser” - niemieckojęzyczny tygodnik o charakterze propolskim, organ Vereinigung der Deutschen in Polen. Stał w opozycji ideowej do tygodnika „Der Deutsche Weg” organu Deutscher Volksverband, reprezentującego poglądy narodowo-niemieckie. Jego redaktorami naczelnymi byli najpierw Arthur H. Lobusch, a następnie Aleksander Hoefig, były dziennikarz „Neue Lodzer Zeitung” oraz badacz regionalny. Tygodnik ukazywał się od lutego 1938 r. do początku września 1939 r. Początkowo czasopismo posiadało 100 prenumeratorów, we wrześniu 1939 r. wzrosła liczba do 800. Nakład gazety wynosił ok. 3000 egzemplarzy. 
sobie za cel wszechstronne informowanie czytelników o wszelkich przejawach życia artystycznego w dziedzinie sztuk plastycznych, literatury, muzyki, teatru oraz kina. Gazety regularnie drukowały twórczość literacką zarówno niemieckich, jak i polskich autorów. Największą popularnością cieszyli się pisarze tworzący literaturę niezbyt ambitną, niewymagającą od czytelnika odpowiedniej wrażliwości literackiej. Ale nie oznacza to, że w gazetach nie pojawiały się utwory ambitniejsze. Okazją do ich publikowania były jubileusze pracy twórczej. W literackim dodatku do „Neue Lodzer Zeitung. Handels- und Industrieblatt” w roku 1903 ukazała się w odcinkach nowela przedstawiciela wiedeńskiego modernizmu Arthura Schnitzlera pt. Der Ehrentag. W tym samym roku opublikowano cykl utwór Stanisława Przybyszewskiego. Zazwyczaj jednak prasa nie była miejscem propagowania nowatorskich tendencji w literaturze. W okresie międzywojennym pojawiały się przekłady twórczości polskich pozytywistów, takich jak: Henryk Sienkiewicz, Bolesław Prus czy Maria Konopnicka ${ }^{24}$.

Lokalna prasa była również miejscem debiutu łódzkich pisarzy. Niewielu z nich miało szanse na publikacje książkowe, stąd na łamach pism pojawiała się regularnie twórczość takich lokalnych autorów, jak: Alexis Drewing, Carl Heinrich Schultz, Joseph Möller, Heinrich Zimmermann, Wilhelm Jess ${ }^{25}$.

\section{Twórczość literacka i różne jej oblicza(II st)}

Rozwój niemieckojęzycznej literatury w Łodzi, począwszy od momentu osiedlenia się pierwszych niemieckojęzycznych osadników w latach dwudziestych XIX w. do wybuchu II wojny światowej, należy rozważać w trzech etapach: pierwszy z nich obejmuje lata od przybycia tkaczy, rękodzielników oraz fabrykantów na tereny Łodzi i trwa dość długo, bo do 1914 r. Druga faza obejmuje I wojnę światową. Trzecia i ostatnia dotyczy okresu międzywojennego. Przyglądając się dokładniej wszystkim trzem etapom, należy zauważyć pewną prawidłowość - rozwój gatunków literackich następuje od form niskich, niewymagających wyszukanego i dbałego języka poetyckiego, aż po gatunki wysokie o wielkich ambicjach, które wymagały od czytelnika odpowiedniej wrażliwości literackiej. W początkowej fazie mamy więc do czynienia z utworami o charakterze okolicznościowym

${ }^{24}$ Przykładowo 3.11.1902 r. w „Illustrierte Sonntagsbeilage. Handels- und Industrieblatt. Neue Lodzer Zeitung”, ukazał się obszerny artykuł poświęcony Marii Konopnickiej z okazji zbliżającego się 25 jubileuszu pracy twórczej.

${ }^{25}$ Badania na temat twórczości literackiej niemieckojęzycznych pisarzy z Łodzi zostały oparte w dużej części na kwerendzie przeprowadzonej w polskich i niemieckich archiwach i bibliotekach. W sumie badaniami zostało objętych ok. 2000 numerów gazet, w tym przede wszystkim niemieckojęzyczne dodatki beletrystyczne: „Illustrierte Sonntagbeilage”, „Illustriertes Sonntagsblatt”, „Illustriertes Wochenblatt”, „Die Welt im Bilde”, „Belletristische Sonntagsbeilage”, „Illustrierte Sonntagsbeilage” czy „Humoristische Beilage”, ukazujące się w Łodzi od 1902 do 1939 r. 
i użytkowym. Jednym z pierwszych świadectw literackich Łodzi jest Gesang zur Weihe des neuerbauten Meisterhauses der Löblichen Weberinnung zu Lodz am 3 ten September $1839^{26}$ - pieśń okazjonalna napisana z okazji poświęcenia Cechu Majstrów Tkackich w Łodzi autorstwa pastora Friedricha Gottloba Metznera ${ }^{27}$. Metzner był pierwszym pastorem pierwszego kościoła ewangelickiego w Łodzi, pod wezwaniem Świętej Trójcy. Zmarł nagle w roku 1852. Parafia była w tym czasie największą w Królestwie Polskim, liczącą około 12 tys. wiernych. Jego działalność na polu kultury była inspiracją dla innych łódzkich duchownych. Środowisko łódzkich pastorów było dość dobrze wykształcone. Przeważnie ukończyli wyższe studia w Niemczech. Wielu z nich interesowało się teologią, filozofią, historią oraz literaturą. Widzieli potrzebę rozwoju duchowego miasta tak w sensie religijnym, jak i literackim. Ich wpływ na rozwój życia kulturalnego Łodzi był znaczący. Wśród pastorów-pisarzy na uwagę zasługuje twórczość trzech najważniejszych: Philippa Kreutza, Rudolfa Gundlacha oraz Augusta Hermanna Müllera.

Pastor Philipp Kreutz urodził się w 1890 r. w Chełmcu, w Galicji. Teologię studiował we Wiedniu i Lipsku. Był wikarym we Lwowie i Trebnitz. W latach 1922-1924 był pastorem w Pabianicach, następnie od 1924 do 1939 w Sompolnie. W 1937 r. wydał tom poezji pt. Zeit und Ewigkeit ${ }^{28}$, natomiast po wojnie w $1953 \mathrm{r}$. - Traum und Tag ${ }^{29}$. W prasie codziennej i czasopismach literackich ukazywały się regularnie jego wiersze. Większość z nich opublikowano w latach dwudziestych XX w. w dodatku do „Neue Lodzer Zeitung”. Utwory Kreutza, podobnie jak innych pisarzy, nie są znane polskiemu czytelnikowi. Wydane zostały w języku oryginału i nigdy nie tłumaczono ich na język polski. Przeważa w nich twórczość o charakterze okolicznościowym. Impulsem do tego rodzaju twórczości były częste podróże Kreutza po Polsce, Niemczech, jak również święta, jubileusze oraz zmieniające się pory roku. Przykładem może być wcześniej wspomniany tom Zeit und Ewigkeit ${ }^{30}$, w którym autor wiele miejsca poświęca wierszom napisanym z okazji nadchodzącej wiosny, lata, zimy i jesieni, poza tym świąt Bożego Narodzenia, Wielkanocy oraz Zielonych Świątek. Swoje miejsce znalazły

${ }^{26}$ F. Metzner, Gesang zur Weihe des neuerbauten Meisterhauses der Löblichen Weberinnung zu Lodz am 3ten September 1839, Lodz: Evangelischen Gemeinde, ca. 1839.

${ }^{27}$ Jako pierwsze polskojęzyczne świadectwa literackie Łodzi zwykło się wymieniać wydaną w roku 1853 monografię O. Flatta pt. Opis miasta Łodzi pod względem historycznym, statystycznym i przemysłowym oraz W. Dłużniewskiego, sztukę z dziejów miasta pt. Wyprawa do Ameryki, powstałą w 1857 r., jak też Pawet Łodzia-Kubowicz (Zdarzenie z pierwszej połowy XVII wieku) z roku 1857.

${ }^{28}$ P. Kreutz, Zeit und Ewigkeit: Gedichte, Lodz 1937. (Jak wykazuje aktualny stan badań, druk nie był do tej pory wznawiany).

${ }^{29}$ P. Kreutz, Traum und Tag: Gedichte, Weißenburg 1953. (Jak wykazuje aktualny stan badań, druk nie był do tej pory wznawiany).

${ }^{30}$ P. Kreutz, Zeit... 
również utwory poświęcone małej ojczyźnie (Heimat), w których ja liryczne podkreśla swój związek z niemczyzną ${ }^{31}$.

Wybitną postacią Kościoła ewangelicko-augsburskiego w Polsce był pastor Rudolf Gundlach ${ }^{32}$. Należał, obok takich pastorów, jak Piotr Angerstein, Juliusz Bursche, Adolf Rondthaler oraz Aleksander Schoenreich, do generacji młodszych duchownych ewangelickich, którzy byli nastawieni patriotycznie wobec kraju, w którym przyszło im żyć. Interesowali się żywo szerszą działalnością wykraczającą poza ramy ich parafii. Rodzina pastora Gundlacha pochodziła z małej miejscowości o nazwie Paproć Duża. Ojciec Jan był nauczycielem szkoły elementarnej dla kolonistów niemieckich i weteranem powstania listopadowego. Rudolf Gundlach miał dziewięcioro rodzeństwa. Urodził się 21 czerwca $1850 \mathrm{r}$. Uczęszczał najpierw do gimnazjum w Łomży, następnie od 1867 r. do gimnazjum w Warszawie. Po ukończeniu gimnazjum udał się do Dorpatu, aby odbyć tam studia teologiczne. Do Łodzi przybył w roku 1898, kiedy został wybrany pierwszym pastorem w parafii Św. Trójcy w Łodzi. Stanowisko to pełnił przez następne 24 lata. Był postacią żywo angażującą się w sprawy łódzkiej społeczności, nie tylko niemieckiej, ale również polskiej i żydowskiej. Zmarł 11 października 1922 r. ${ }^{33}$ Był znakomitym mówcą i kaznodzieją, poetą, autorem i thumaczem wielu pieśni o charakterze religijnym. Był autorem Śpiewnika dla Kościoła EwangelickoAugsburskiego w Królestwie Polskiem (1899), w którym znalazły się pieśni niedzielne, adwentowe, wielkanocne, z okazji chrztu świętego, konfirmacji, poranne, wieczorne, o sądzie i życiu wiecznym, a wśród nich takie tytuły, jak: Progi święte przestapilem (19), Otwórzcie się szeroko (40), Jutrzenko nowych czasów (101), Wolę Swa odwieczna święta (125), Ojca czcić i matkę swoja (126), Święty, święty, święty Boże (127), O dobry Boże, życia drogi (137), Bóg z łaski ten grzeszy świat (213), Przymierze chrztu dziś (306), Boże miły Ojcze w niebie, Tyś... (328), Boże mity Ojcze w niebie, raczki... (338), Bieleja niwy i powisty kłosy (417). W powyższych pieśniach Gundlach odwołuje się przede wszystkim do wartości religijnych i ukazuje głęboką wiarę w Boga. Podobne przesłanie niesie ze sobą twórczość innego łódzkiego poety Augusta Hermanna Müllera, pastora w kościele św. Jana, autora tomiku wierszy pt. Waldblumen, który ukazał się w 1902 r. ${ }^{34}$ August Hermann Müller był pastorem o poglądach ortodoksyjnych. Brał aktywny udział w różnych inicjatywach kościelnych, w tym angażował się intensywnie w działalność charytatywną. Twórczość łódzkich pastorów nie była wybitna. Tworzyli

\footnotetext{
${ }^{31}$ Por. wiersze: Das deutsche Lied, Lied der Auslanddeutschen, [w:] P. Kreutz, Zeit...

${ }^{32}$ Por. M. Budziarek, Skromna wielkość, Rudolf Gustaw Gundlach (1850-1922), [w:] Łodzianie, Łódź 2000.

${ }^{33}$ A. Milker, Konsistorialrat Pastor Rudolf Gundlach, „Illustriertes Sonntagsblatt. Beilage zur „Neuen Lodzer Zeitung”, Nr. 23, 15. Oktober 1922, s. 1-2 i 4.

${ }^{34}$ A. H. Müller, Waldblumen, Lodz 1902. (Jak wykazuje aktualny stan badań, druk nie był wznawiany. Egzemplarz książki znajduje się w Martin-Opitz-Bibliothek w Herne, sygnatura ADMB 05420).
} 
oni literaturę prostą, która miała dotrzeć do przeciętnego czytelnika. Ich utwory służyły głównie rozpowszechnianiu prawd wiary wśród prostych ludzi.

Oprócz tekstów o charakterze religijnym i okolicznościowym w pierwszym okresie pojawiają się również krótkie teksty o charakterze humorystycznym. Przykładem może tu być publikacja Wilfrieda Spectatora (ps. Reinhold Piel) z 1913 pt. 'Ne Mütze voll Witze aus Lodz und Pabianice ${ }^{35}$. Autor zebrał w niej dowcipy z Łodzi i Pabianic częściowo napisane w łódzkiej niemczyźnie (Lodzerdeutsch) ${ }^{36}$. Inspiracją do zebrania tych śmiesznych historyjek była chęć powstrzymania konfliktów, które miały miejsce w takim wielokulturowym społeczeństwie, jakim była Łódź przełomu wieków. Tak oto autor pisał we wstępie na ten temat: „Jeśli wam, kartom tej książki, uda się zjednoczyć ludzi, jeśli uda się wam wskazać na te właściwości charakterów, które są przeszkodą na drodze do pojednania, [...] to spełniłyście swe zadanie!" ${ }^{37}$ Bohaterami wiców stali się „lodzermensche” oraz ich cechy, składające się na mentalny obraz miasta. Autor czyni aluzje pod adresem twórców prasy codziennej, wytykając im pogoń za tanią sensacją jak w dowcipie pt. Sekutnica albo jak to wyglada $w$ gazecie „Echo”, ukazuje poza tym spryt, przebiegłość łódzkich handlarzy oraz chęć zysku tanim kosztem jak np. w dowcipie Napisane jest w księdze, który brzmi:

Pewien powroźnik dostarczał do fabryki linki konopne, które jednak już po trzech miesiącach do niczego się nie nadawały. Jednocześnie okazało się, że sznury zrobione były ze starych, zleżałych konopi, a tylko z wierzchu pokryte warstwą dobrego, świeżego materiału. Kiedy zażądano wyjaśnień, powroźnik wzruszył tylko ramionami i odparł: „No, przecież napisane jest w księdze: Zło dobrem zwyciężaj!"38

Tematyka „lodzermenscha” pojawia się nie tylko w dowcipach. Kolejne lata rozwoju łódzkiej literatury przynoszą rozwój krótkich utworów prozatorskich, takich jak obrazki, szkice publicystyczne, reportaże oraz felietony. Do najbardziej znanych przedstawicieli tych gatunków zalicza się Carla Heinricha Schultza, Heinricha Zimmermanna oraz Bertę Teplitzką, autorkę tomu Lodzer Typen ${ }^{39}$. Jej książka jest

${ }^{35}$ Autorka odnalazła dwa egzemplarz książki w Martin-Opitz-Bibliothek w Herne (sygnatury: Gd 576 Y oraz Bk 2 I 06886). Nie wyklucza się jednak, że kolejne egzemplarze istnieją w prywatnych zbiorach.

${ }^{36} \mathrm{~W}$ wyniku badań i kwerend nad niemieckojęzyczną literaturą Łodzi autorka natrafiła na teksty literackie pisane w Lodzerdeutsch/Lodzer Deutsch. Są to m. in. fragmenty dramatu Bruno Raymonda, Isabella. Motive aus der Komödie der Ehe, Lodz 1928, Wilfrieda Spectatora (ps. Reinhold Piel), 'Ne Mütze voll Witze aus Lodz und Pabianice, Lodz 1913; C. H. Schultza, Zeitgemäße Betrachtungen, „Der Deutsche Wegweiser”, Folge 19, v. 3. Juli 1938, s. 8; C. H. Schultza, Pfingstgespräche, „Der Deutsche Wegweiser”, Folge 2, v. 28, Mai 1939, s. 7; C. H. Schultza, Lodzer Deutsch „Der Deutsche Wegweiser”, Folge 19, v. 3, Juli 1938, s. 7 i in.

${ }^{37}$ W. Spectator (ps. Reinhold Piel), 'Ne Mütze voll Witze aus Lodz und Pabianice, Lodz 1913, thum. za M. Półrola, Cały ten interes, ,Tygiel Kultury”, nr 7-9/2008.

${ }^{38}$ Ibidem.

${ }^{39}$ B. Teplitzka, Lodzer Typen, Lodz 1913. 
zbiorem portretów, publikowanych na początku XX w. na łamach „Neue Lodzer Zeitung”. Ilustruje podobnie jak wcześniej wspomniany zbiór Wilfrieda Spectatora mentalność miasta sprzed I wojny światowej, jego tożsamość oraz wielokulturowy charakter. Jednakże Teplitzka dokonuje pełniejszego wglądu w łódzkie typy. Jej teksty są utrzymane w sposób lekko ironiczny i żartobliwy.

W Łodzi na przełomie wieków powstaje również literatura poważniejsza, pozbawiona cech żartu czy humoru. Należy do niej poezja, która jest szczególnie ulubionym gatunkiem drukowanym w prasie codziennej oraz dodatkach kulturalnych. Na łamach łódzkiej prasy publikują jak na ówczesne czasy najbardziej znani autorzy: Eduard Habermann, Marie Hirschbein, Wilhelm Jess, Alxis Drewing, Gustav Krüger, Julian Will, Sigismund Banek oraz wcześniej wspomniany Carl Heinrich Schultz. Wśród nich należy wyodrębnić grupę literatów zaangażowanych, którzy wykazują w swych tekstach tendencje do artykułowania sympatii politycznych. Uwidoczniają się one szczególnie w okresie międzywojennym, kiedy na gruncie łódzkim zaczynają ścierać się ugrupowania o różnym rodowodzie społeczno-politycznym: sympatycy ugodowej polityki wobec Polski i Polaków, zwolennicy polityki zagranicznej Hitlera oraz socjaliści. Prawie każde z tych ugrupowań stworzyło utwór, na kształt manifestu, w którym zawierała się koncepcja niemczyzny w Polsce. Jednym z autorów, zaangażowanych politycznie był wspomniany wcześniej Carl Heinrich Schultz (1882-1940), polski patriota niemieckiego pochodzenia, zagorzały przeciwnik narodowego socjalizmu, swego rodzaju spiritus movens w środowisku Niemców ugodowo nastawionych wobec Polski i Polaków. Jednym z ważniejszych dzieł Carla Heinricha Schultza jest utwór pt. Pieśń polskiego Niemca, konkurujący z Lied für Auslanddeutsche autorstwa Juliana Willa, będącego manifestem innego ugrupowania stojącego na przeciwległym biegunie poglądów politycznych, a mianowicie narodowych socjalistów, kwestionujących w międzywojniu polską państwowość i za wszelką cenę podkreślających związek niemczyzny zagranicznej z Rzeszą ${ }^{40}$. Wiersz Schultza w polskim przekładzie brzmi następująco ${ }^{41}$ :

Przodkowie nasi ongiś tu ściągali

$\mathrm{z}$ rozlicznych stron, $\mathrm{z}$ niemieckich krain,

tam z trudem koniec z końcem wiązali,

tu zacząć wszystko od nowa zamierzali.

Przybyli zatem do polskiej krainy

życie budując od podwalin,

tutaj znaleźli drugą ojczyznę,

której swe serca bez reszty oddali.

${ }^{40}$ Fragment wiersza opublikowany m. in. w artykule R. Gerlach-Damaschke, op. cit. oraz O. Heike, op. cit.

${ }^{41}$ [Tłum. Małgorzata Półrola]. 
To los tak chciał, to los nas wiąże

z naszym ojczystym krajem, z Polską.

Choć czasy, choć ludzie się zmieniali, myśmy na zawsze Niemcami zostali.

Niemiecką duszę, niemiecką krew mamy,

obojgu wierni będziemy bez granic.

Lecz tu, gdzieśmy blask świata ujrzeli i życia naszego karty spisywać poczęli, choć różnie się toczyć będą losy Polski, my jej na zawsze dochowamy wierności!

To los tak chciał, to los nas wiąże

z naszym ojczystym krajem, z Polską ${ }^{42}$.

Autor w wierszu daje wyraz koncepcji roli niemczyzny w Polsce, jaką prezentowała organizacja Vereinigung der Deutschen in Polen. Członkowie tejże organizacji, w tym również Schultz uważali, że społeczność niemiecka w Polsce powinna być lojalna wobec państwa polskiego, które, z kolei, powinno stać się ich nową ojczyzną. Widzieli również konieczność zachowania kultury i języka niemieckiego w Polsce ${ }^{43}$. Polityczne zaangażowanie Schultza zaowocowało pod koniec lat trzydziestych XX w. cyklem utworów publikowanych na łamach tygodnika „Der Deutsche Wegweiser”, którymi autor odwoływał się w formie i stylu do tradycji tzw. nowej rzeczywistości (Neue Sachlichkeit) - kierunku w literaturze Republiki Weimarskiej, którego przedstawicielami byli tacy pisarze, jak Erich Kästner, Bertolt Brecht czy Kurt Tucholsky. Autor w sposób krytyczny piętnował przywódców narodowosocjalistycznych oraz politykę zagraniczną Trzeciej Rzeszy ${ }^{44}$.

Wśród twórczości wierszowanej Łodzi na uwagę zasługuje wcześniej wspomniany nurt literatury ojczyźnianej, która na początku XX w. zaczęła ewoluować w kierunku propagowania najbardziej konserwatywnych idei Drugiej Rzeszy oraz piśmiennictwa tzw. substancji narodowej, to jest ujmowania narodu jako wielkości zmistyfikowanej ${ }^{45}$. Przedstawicielami tego nurtu na gruncie łódzkim byli Julian Will oraz Sigismund Banek. Julian Will (1890-1941) był nauczycielem, dziennikarzem oraz aktywnym działaczem organizacji o nazwie Deutscher Verein für Lodz und Umgebung. Angażował się również w działalność Deutsch-Evangelischer

${ }^{42}$ Wiersz ukazał się na łamach „Der Deutsche Wegweiser”, 6 listopada 1938 r. .

${ }^{43}$ An alle Deutschen in Polen! Rückblick und Mahnung - Deutscher erwache!, „Der Deutsche Wegweiser", 27 lutego 1938, s. 1.

${ }^{44}$ Twórczość C. H. Schultza została zebrana w tomie: M. Kucner (red.) przy współpracy z Wolfgangiem Kesslerem, Literackie i nieliterackie obrazy miasta. Łódź przełomu wieków oczami niemieckojęzycznego autora - Carla Heinricha Schultza/Nicht nur literarische Bilder einer Stadt. Lodz in den Augen eines deutschsprachigen Autors - Carl Heinrich Schultz, Łódź 2011.

${ }^{45}$ Por. Cz. Karolak, W. Kunicki, H. Orłowski, op. cit. 
Landesschulverband. W 1928 r. został wybrany na posła do Sejmu. Urodził się w niewielkiej miejscowości, Liciszewo, koło Lipna na Kujawach. W latach trzydziestych XX w. przybył do Łodzi, gdzie związał się z narodowosocjalistycznym Deutscher Volksverband, którego organem prasowym była „Lodzer Freie Presse”. Julian Will był postacią o dość spójnych poglądach politycznych. Zawsze opowiadał się za zachowaniem niemczyzny, niemieckiej kultury i języka na ziemiach polskich. W tym duchu poświęcił się pracy nauczycielskiej, którą wykonywał w szkołach w Sompolnie, Rawiczu i Zgierzu. Mimo oddania dla społeczności niemieckiej, hitlerowcy, którzy wkroczyli w 1939 r. do Polski, uznali jego postawę polityczną za zbyt mało lojalną wobec narodu i państwa niemieckiego, co w konsekwencji doprowadziło do samobójczej śmierci w roku 1941. Obok Willa poetą zaangażowanym politycznie był Sigismund Banek (1896-1945). Urodził się na Kujawach w miejscowości Synogać. Lata swojej młodości spędził w Sompolnie, gdzie ukończył szkołę podstawową. Z wykształcenia był nauczycielem, uczęszczał do niemieckiego Seminarium Nauczycielskiego w Łodzi. Od 1930 r. zaangażował się w działalność Lodzer Deutsches Schul- und Bildungsverein (LDSBV). W ramach tego związku organizował pracę kół młodzieżowych, wieczory autorskie oraz spotkania muzyczne. Był również bibliotekarzem, działaczem społecznym i politycznym. Od 1939 r. pracował jako kierownik biblioteki miejskiej. Jego twórczość literacką chętnie publikowały niemieckojęzyczne gazety w Łodzi. W 1944 r. wstąpił do Wehrmachtu. Zginął najprawdopodobniej w okolicach Poznania na polu walki.

W swoich utworach obaj autorzy podkreślali przywiązanie do stron ojczystych [Heimat], szczególne posłannictwo narodu niemieckiego w dziejach ludzkości, jak również walkę z bliżej nieokreślonym wrogiem narodu niemieckiego. Te i inne jeszcze motywy znajdują się w wierszach obu autorów zebranych w tomach, które zostały wydane w okresie międzywojennym, należą do nich: Heimatklänge: deutsche Dichtungen aus dem ehemaligen Kongreßpolen ${ }^{46}, \mathrm{Du}$ stehst in großer Schar: Junge deutsche Dichtung aus Warthe- und Weichselland ${ }^{47}$, Werk und Wehr ${ }^{48}$, Rufer des Ostens ${ }^{49}$, Aufbruch und Heimkehr ${ }^{50}$.

${ }^{46}$ [b.a.] Heimatklänge: deutsche Dichtungen aus dem ehem. Kongreßpolen. Mit Widmung von Albert Breyer an „die dankbaren Heimatgenossen”, Lodz 1925. (Jak wykazuje aktualny stan badań, druk nie był do tej pory wznawiany).

${ }^{47}$ Du stehst in großer Schar: junge deutsche Dichtung aus Warthe- und Weichselland, hrsg. von Heinz Kindermann, Breslau 1939. (Jak wykazuje aktualny stan badań, druk nie był do tej pory wznawiany).

${ }^{48}$ S. Banek, Werk und Wehr, Posen 1939. (Jak wykazuje aktualny stan badań, druk nie był do tej pory wznawiany).

${ }^{49}$ H. Müller (red.), Rufer des Ostens, Posen 1941. (Jak wykazuje aktualny stan badań, druk nie był do tej pory wznawiany).

${ }^{50}$ S. Banek, Aufbruch und Heimkehr, Berlin 1940. (Jak wykazuje aktualny stan badań, druk nie był do tej pory wznawiany). 
Znacznie skromniej na tym tle przedstawia się twórczość dramatyczna i prozatorska: dramaty, opowiadania, nowele i powieści. Te ostatnie zaczęly ukazywać się krótko przed wybuchem II wojny światowej, kiedy do głosu doszło kolejne pokolenie niemieckich osadników, w dużej mierze spolonizowanych oraz kształconych na uniwersytetach w Europie Zachodniej. Wiele z tej twórczości powstało już w języku polskim, jak np. powieści Bruno Raymonda - Ucieczka przez błękit nieba z $1935 \mathrm{r}^{51}$ lub Miłość, student a wojna ${ }^{52}$, która ukazała się w roku 1933. Wcześniej niż powieści pojawiły się w twórczości niemieckojęzycznych łodzian dramaty. Jednym z pierwszych utworów tego typu była książka Wilhelma Jessa z 1910 r. pt. Das Verbrechen auf Jasna Góra oder Pater Damasy ${ }^{53}$, w której autor przedstawia autentyczną historię Damazego Macocha, zakonnika klasztoru na Jasnej Górze, który dopuścił się niechlubnych czynów, za co został skazany na kilka lat więzienia. Oprócz Wilhelma Jessa twórczością dramatyczną zajmował się wcześniej już wspominany B. Raymond, autor utworu dramatycznego pt. Isabella. Motive aus der Komödie der Ehe, który powstał w roku $1928^{54}$. Raymond podejmuje w dramacie wiele kwestii. Jedną z nich jest zagadnienie instytucji małżeństwa, która jawi się autorowi jako relikt przeszłości. Porusza również zagadnienie stosunków między właścicielami fabryk a robotnikami. Dla łódzkiego społeczeństwa, które było wyraźnie spolaryzowane, kwestia podziałów klasowych była bardzo ważna. Dramaturgia B. Raymonda jest więc świadectwem jego otwarcia na sprawy społeczne.

Oba utwory, Raymonda i Jessa, są utworami przeznaczonymi dla prostego czytelnika. Zarówno fabuła, jak i bohaterowie są nakreśleni w sposób schematyczny, niezaskakujący. Autorzy często odwołują się do sytuacji społecznej, w której bieda gra nadrzędną rolę. Rzadko, natomiast, łódzkie utwory podejmują zagadnienia związane z odrębnością narodową. Sytuację tę zapewne thumaczy fakt, iż niemieckojęzycznym łodzianom brakowało poczucia świadomości narodowej. Przybywający w pierwszej połowie XIX w. osadnicy nie mieli poczucia przynależności do określonego narodu. Zjednoczenie ziem niemieckich nastąpiło dopiero w 1871 r. Pochodzili więc z różnych krajów niemieckich, takich jak Śląsk, Prusy, Saksonia, Czechy oraz Wielkopolska. Pielęgnowali odrębne tradycje kulturowe, nawet język, którym się posługiwali nie miał jednolitej formuły. Mówili bowiem różnymi dialektami. Ich język posiadał cechy dialektu śląskiego, saksońskiego, pruskiego i gwary szwabskiej ${ }^{55}$. Kiedy przybyli do Łodzi, miasto

${ }^{51}$ B. Raymond, Ucieczka przez błękit nieba, Łódź 1935. (Jak wykazuje aktualny stan badań, druk nie był do tej pory wznawiany).

${ }^{52}$ B. Raymond, Miłośćc, student a wojna, Łódź 1933. (Jak wykazuje aktualny stan badań, druk nie był do tej pory wznawiany).

${ }^{53}$ W. Jess, Das Verbrechen auf Jasna Góra oder Pater Damasy, Łódź 1910. (Jak wykazuje aktualny stan badań, druk nie był wznawiany).

${ }^{54}$ B. Raymond, Isabella. Motive aus der Komödie der Ehe, Lodz 1928. (Jak wykazuje aktualny stan badań, druk nie był wznawiany).

${ }^{55}$ Informacja od Aleksandry Czechowskiej-Błachiewicz, por. też R. Sadziński, Osadnictwo niemieckie $w$ regionie tódzkim $w$ świetle faktów językowych, [w:] Niemcy $w$ dziejach Łodzi, 
znajdowało się pod zaborem rosyjskim, nie stali się więc Polakami, lecz poddanymi cara. W okresie I wojny światowej, kiedy miasto zajęły wojska niemieckie, w części niemieckojęzycznych łodzian zaczęła budzić się świadomość niemiecka, która znowu ze względów politycznych musiała zgasnąć po zakończeniu wojny. Kiedy odrodziło się państwo polskie, Niemcy łódzcy przyjęli obywatelstwo polskie i w dużej mierze zasymilowali się z Polakami. Brak poczucia narodowego spowodował, że w dorobku niemieckojęzycznych autorów nie znalazła się żadna powieść na miarę Reymontowskiej Ziemi obiecanej ${ }^{56}$, w której tak barwnie pisarz namalował ówczesny portret miasta i jego polskich, niemieckich i żydowskich mieszkańców.

Kwestie tożsamości oraz wielokulturowości jednak pojawiają się, ale dość późno, bo dopiero w 1938 r., kiedy ukazuje się powieść B. Raymonda pt. W poszukiwaniu ojczyzny ${ }^{57}$. Autor wprowadza do powieści bohatera o niezidentyfikowanym poczuciu narodowym, niewiele wiedzącym o swoim pochodzeniu. Udaje się on w podróż, która ma mu przywrócić poczucie tożsamości. Powieść znacznie odbiega, zarówno fabułą, jak i konstrukcją głównego bohatera, od szeregu utworów, skierowanych do prostego czytelnika. Autor robi liczne odwołania do filozofii, religii wschodnich. W sposób nieoczywisty buduje fabułę, w której jest wiele niedomówień. Jednakże powieść i cała twórczość Raymonda, choć zapewne wybijająca się na tle wielu prostych tekstów, stanowi niewielką zaledwie część tego, co należy uznać za tendencję dominującą w rozwoju niemieckojęzycznej literatury.

Łódzcy autorzy zamiast obszernych powieści preferują krótkie opowiadania, które ze względu na swoją objętość mogą zostać opublikowane na łamach lokalnej gazety. W krótkich formach prozatorskich najczęściej zwracano uwagę na kwestie społeczne. Akcentowano takie problemy, jak bieda, wyzysk, niesprawiedliwość społeczna oraz podejmowano przy tym krytykę postaw moralnych. Demaskując najbardziej palące problemy epoki, utwory te zyskiwały charakter moralizatorsko-dydaktyczny, który przybliżał tę twórczość do naturalizmu. Wielu niemieckojęzycznych pisarzy, w tym Carl Heinrich Schultz czy Olenka Teschner, w swojej twórczości wykorzystywało założenia artystyczne i estetyczne naturalizmu. Bohaterami byli zazwyczaj ludzie z nizin społecznych, miejska biedota, artyści i robotnicy. Centralnymi postaciami wielu utworów stawali się ponadto

Łódź 2001, s. 259-280; O. Kossmann, Lodzer Deutsch - ein Stück der Heimat, [w:] Ein Lodzer Heimatbuch, Hannover 1967, s. 200-214; R. Sadziński, W. Sadziński, Die Sprache der Lodzer Deutschen, [w:] Studien und Forschung zur Deutschland-und Osterreichkunde in Polen, Beiträge der internationalen wissenschatlichen Konferenz des VPG, L. Meissner, G. Pawłowski (Hrsg.), Warszawa 2011, s. 329-339.

${ }^{56}$ W. S. Reymont, Ziemia obiecana, Warszawa 1899.

${ }^{57}$ Por. m. in. C. H. Schultz, Hunger, ,Illustrierte Sonntagsbeilage zur Neuen Lodzer Zeitung”, Nr. 38, 31. August, 13. September 1914, s. 284-285. (Jak wykazuje aktualny stan badań, tekst nigdy nie ukazał się w formie publikacji książkowej). 
pisarze pozbawieni talentu literackiego, kopiści nieudolnie odtwarzający twórczość innych wielkich poetów, wielu z nich nie mogło utrzymać swoich rodzin i popadało $\mathrm{w}$ skrajną depresję ${ }^{58}$. W pewnym sensie utwory łódzkich pisarzy mogłyby stać się próbą autorefleksji łódzkiego środowiska literackiego. Ich bohaterowie byli tacy jak uformowało ich środowisko i możliwości. Często podejmowali działania służące zaspokajaniu potrzeb biologicznych oraz żądzy posiadania, były więc walką o byt. Przyglądając się jednak dokładniej tej twórczości, należy zauważyć, iż nie jest to literatura naturalistyczna sensu stricto. Zazwyczaj utwory te łamią konwencję naturalistyczną poprzez wprowadzenie tzw. happy endu. W opowiadaniu Schultza pt. Hunger ${ }^{59}$ bohater targany walką o byt, stojący na krawędzi katastrofy finansowej, popełnia przestępstwo, za które ma być oskarżony przed sądem. Jednakże w wyniku postępowania zostaje uniewinniony. Ale nie jest to reguła. W opowiadaniu łódzkiego pisarza Maxa Adolphi, pt. Das Schicksal ${ }^{60}$, główna bohaterka, arystokratka, przeżywa degradację społeczną. Musi opuścić swoje strony rodzinne, przenieść się do Łodzi i pracować jako uboga robotnica w miejscowej fabryce. W innym opowiadaniu Schultza, pt. Der Retter. Aus dem russischen Leben ${ }^{61}$, bohater sam stacza się na dno społeczne, chcąc uratować od biedy swojego przyjaciela, innego pisarza. Kolejnym elementem, który jest charakterystyczny dla tej twórczości, to sposób przedstawiania rzeczywistości i kreacji bohaterów. Autorzy łódzcy nie stosują charakterystycznych dla naturalistów nowatorskich sposobów ekspresji. Nie posługują się brutalnymi opisami rzeczywistości ani elementami turpizmu. Ich bohaterowie nie mówią ani gwarą, ani nie używają drastycznego słownictwa. Ich język nie szokuje, jest prosty w swoim przekazie, pozbawiony zbędnych metafor. Ma na celu przekazać w sposób jasny treść a wraz z nią przesłanie.

\section{Uwagi końcowe}

Warunki społeczno-kulturowe na przełomie wieków w Łodzi nie zachęcały do tworzenia wybitnej literatury. Uznani literaci jak Reymont czy Döblin pojawiają się w tym wielonarodowym mieście tylko przejściowo. Miejscowi pisarze

${ }^{58}$ B. Raymond, W poszukiwaniu ojczyzny, Łódź 1938. (Jak wykazuje aktualny stan badań, druk nie był wznawiany).

${ }^{59}$ Ibidem.

${ }^{60}$ M. Adolphi, Das Schicksal, „Illustriertes Sonntagsblatt der Neuen Lodzer Zeitung”, Nr. 48, 2.12.1923, s. 2-5. (Jak wykazuje aktualny stan badań, tekst nigdy nie ukazał się w formie publikacji książkowej).

${ }^{61}$ C. H. Schultz, Der Retter. Aus dem russischen Leben, „Illustrierte Sonntags-Beilage zur Nr. 36 des Handels- und Industrieblatt. Neue Lodzer Zeitung", 22. August (4. September) 1906, s. 282-283. (Jak wykazuje aktualny stan badań, tekst nigdy nie ukazał się w formie publikacji książkowej). 
nie potrafią wytworzyć trwałego środowiska literackiego, które nadawałoby ton życiu kulturalnemu miasta. Brak jest również szerszej recepcji tych utworów. Wyjątek stanowi tzw. Heimatliteratur, która znajduje swoje miejsce w licznych antologiach oraz opracowaniach niemieckojęzycznych badaczy niemczyzny zagranicznej. Wielu lokalnych autorów, którzy tworzyli na łamach gazet, jest przez wiele lat zapomnianych. Literatura niemieckojęzycznych łodzian, wyrosła na tak niepewnym gruncie, ma jednak swój charakterystyczny rys, który w znacznym stopniu odróżnia ją od literatury innych regionów. Powstające tu utwory można określić jako literaturę prostą, posługującą się oczywistymi schematami i niewyszukanym językiem z tendencją do literatury bardziej ambitnej, o czym świadczą chociażby niektóre utwory Raymonda. Cechuje ją ponadto brak jej jednolitej formuły, pewnej wspólnoty tematycznej. Utwory powstają zazwyczaj w znacznym oderwaniu od tendencji widocznych w literaturze narodowej. Mimo iż wartość artystyczna i estetyczna wielu utworów jest wątpliwa, to bezsprzecznie przybliżają one ówczesną przestrzeń literacką wielonarodowej Łodzi. To właśnie te proste, nieskomplikowane w strukturze i języku teksty, przybliżają ówczesną przestrzeń literacką wielonarodowego miasta, którą należy badać. Z dzisiejszej perspektywy łódzka literatura przełomu wieków może być odpowiedzią na współczesne poszukiwania tożsamości małych ojczyzn. Jest ona bowiem jednym z ważniejszych elementów, które złożyły się na regionalne poczucie odrębności. 